\title{
Pengaruh Alat Permainan Edukatif Berbasis Lingkungan Terhadap Hasil Pembelajaran Sains
}

\author{
Riska Djamalu ${ }^{1}$, Rusdin Djibu ${ }^{2}$, Rapi Us.Djuko ${ }^{2)}$ \\ Jurusan Pendidikan Luar Sekolah, Fakultas Ilmu Pendidikan, Universitas Negeri Gorontalo \\ riskadjamalu1705@gmail.com,rusdindjibu@ung.ac.id, rapidjuko@ung.ac.id
}

Received: 24 Mei 2021; Revised: 18 Juni 2021; Accepted: 29 Juni 2021

\begin{abstract}
The research objective is to find out the impact of environment-based educative game on science learning outcomes at TK (Kindergarten) Tribrata in Tupa Village, Bulango Utara Sub-district, Bone Bolango District. The research is classified as quasi experiment research, which employs a nonequivalent control group design. The research samples, which are decided based on class with most student, are 30 students from Class B, where the class is divided into two, and each class contains 15 students, class B1 as control group and class B2 as experimental group. Meanwhile, the technique of analysis applies descriptive statistics and inferential statistics, while the hypothesis test uses a t-test assisted by Microsoft Excel and SPSS version 16 programs. In reference to the of analysis using SPSS version 16 by selecting independent sample test, value of Sig (2-tailed) is 0,039 , and the value is lower than 0,05 . Meanwhile, the result of $t_{\text {count }}$ is 2.166 , and it is higher than 2.048. the value of Sig (2-tailed) is lower than $\mathrm{t}_{\text {count }}$ so that Ha is accepted and H0 is rejected, and it means the use of environment-based educative game owns a significant impact. Keywords: Science Learning Outcomes, Environmental-Based Educative Game.
\end{abstract}

\begin{abstract}
ABSTRAK
Penelitian ini bertujuan untuk mengetahui pengaruh dari alat permainan edukatif berbasis lingkungan terhadap hasil pembelajaran sains di TK Tribrata Desa Tupa Kecamatan Bulango Utara Kabupaten Bone Bolango. Jenis penelitian yang digunakan adalah Quasi Eksperimen sedangkan desain penelitian yang digunakan adalah Nonequivalent Control Group Design. Sampel yang digunakan dalam penelitian ini yaitu berdasarkan kelas dengan jumlah peserta didik terbanyak yaitu kelas B, berjumlah 30 peserta didik yang dibagi dua kelas: kelas B1 sebagai kelas kontrol 15 peserta didik dan kelas B2 sebagai kelas eksperimen 15 peserta didik. Teknik analisis yang digunakan adalah analisis statistik deskriptif dan analisis statistik inferensial,sedangkan uji hipotesis yang digunakan adalah uji t-test atau uji $\mathrm{t}$ dengan dibantu oleh program komputer Microsoft Excel dan program SPSS versi 16. Berdasarkan perhitungan uji analisis menggunakan bantuan program SPSS versi 16 dengan memilih uji independent sampel test diperoleh nilai Sig (2-tailed) sebesar 0.039 dan nilai ini < dari 0.05, sedangkan dari hasil $t_{\text {hitung }}$ diperoleh nilai sebesar 2,166 dan nilai ini $>$ dari 2,048. Karena nilai Sig (2-tailed) $<\propto$ atau $t_{\text {hitung }}$ maka Ha diterima dan Ho ditolak. Artinya penggunaan alat permainan edukatif berbasis lingkungan terdapat pengaruh yang signifikan.
\end{abstract}

Kata Kunci: Hasil Pembelajaran Sains, Alat Permainan Edukatif Berbasis Lingkungan.

C2021 by Riska Djamalu, Rusdin Djibu, Rapi Us. Djuko Under the license CC BY-SA 4.0

\section{PENDAHULUAN}

Pendidikan anak usia dini bertujuan untuk mengembangkan seluruh potensi anak (the whole child) agar kelak dapat berfungsi sebagai manusia yang utuh 
sesuai falsafah suatu bangsa (Suyanto, 2005:5). Pendidikan anak usia dini (PAUD) mengalami perkembangan yang sangat pesat. Hal ini ditandai dengan terus bertambahnya jumlah lembaga PAUD. Taman kanak-kanak (TK), radiatul atfal (RA), kelompok bermain (KB), taman penitipan anak (TPA), dan PAUD sejenis lainnya dengan nama yang bervariasi banyak bermunculan. Hal ini juga sebagai bukti meningkatnya kesadaran orang tua dan guru tentang pentingnya PAUD.

Anak usia dini adalah individu yang sedang mengalami proses pertumbuhan dan perkembangan yang sangat pesat, bahkan dikatakan sebagai lompatan perkembangan. Anak usia dini memiliki rentang usia yang sangat berharga dibanding usia-usia selanjutnya karena perkembangan kecerdasannya sangat luar biasa. Usia tersebut merupakan fase kehidupan yang unik, dan berada pada masa proses perubahan berupa pertumbuhan, perkembangan, pematangan dan penyempurnaan, baik pada aspek jasmani maupun rohaninya yang berlangsung seumur hidup, bertahap dan berkesinambungan.

Kehidupan anak usia dini tidak dapat lepas dari sains, kreativitas dan aktivitas sosial. Oleh sebab itu, pendidik hendaknya dapat menstimulasi peserta didik dengan berbagai kegiatan yang terkait dengan sains dan teknologi. Kegiatan sains memungkinkan peserta didik melakukan eksplorasi terhadap berbagai benda, baik benda hidup maupun benda tak hidup yang ada disekitarnya.

Menurut Sumanto dkk dalam Putra (2013:40), sains merupakan cara mencari tahu tentang alam secara sistematis untuk menguasai pengetahuan, fakta, konsep, prinsip, proses penemuan, dan memiliki sikap ilmiah. Dari definisi tersebut sangat efektif bahwa pendidikan sains menekankan pada pembelajaran pengalaman secara langsung agar dapat menjelajahi dan memahami alam sekitar secara ilmiah. Sedangkan Conant dalam Nugraha (2008: 3) mendefenisikan sains sebagai suatu deretan konsep serta skema konseptual yang berhubungan satu sama lain. Yang tumbuh sebagai hasil serangkaian percobaan dan pengamatan serta dapat diamati dan di uji coba lebih lanjut. Sains berhubungan erat dengan kegiatan penelusuran gejala dan fakta-fakta alam yang ada di sekitar peserta didik. 
Dengan sains dapat melatih peserta didik menggunakan lima inderanya untuk mengenal berbagai gejala benda dan gejala peristiwa. Peserta didik dilatih untuk melihat, meraba, membau, merasakan dan mendengar. Semakin banyak keterlibatan indera dalam belajar, maka peserta didik akan semakin memahami apa yang dipelajari. Pengetahuan baru akan diperoleh dari hasil penginderaanya dengan berbagai benda yang ada disekitarnya. Pengetahuan yang diperolehnya akan berguna sebagai modal berpikir lanjut. Melalui proses sains, peserta didik dapat melakukan percobaan sederhana. Percobaan tersebut melatih peserta didik menghubungkan sebab dan akibat dari suatu perlakuan sehingga melatih anak berpikir logis. Dengan mengembangkan kemampuan berpikir, peserta didik diharapkan dapat mengolah perolehan belajar dan menemukan bermacam-macam alternatif pemecahan masalah. Salah satu hasil belajar yang harus dicapai adalah peserta didik dapat mengenal berbagai konsep sains sederhana dalam kehidupan sehari-hari.

Karena dunia peserta didik adalah bermain maka pembelajaran dapat dilakukan melalui kegiatan bermain sambil belajar atau belajar seraya bermain. Bermain adalah suatu kegiatan yang dilakukan dengan atau tanpa mempergunakan alat yang menghasilkan pengertian atau memberikan informasi, memberi kesenangan maupun mengembangkan imajinasi pada peserta didik (Sudono A, 2000: 1).

Melalui bermain peserta didik diajak untuk bereksplorasi, menemukan dan memanfaatkan objek-objek yang dekat dengannya, sehingga pembelajaran menjadi lebih bermakna. Selain itu, belajar dengan bermain memberi kesempatan kepada peserta didik untuk memanipulasi, mengulang-ulang, menemukan sendiri, mempraktekkan dan mendapatkan bermacam-macam konsep serta pengertian yang tidak terhitung banyaknya. Dalam melakukan pembelajaran sambil bermain, peserta didik memerlukan media instruksional yaitu Alat Permainan Edukatif (APE). Alat yang dimaksud merupakan segala seuatu yang dapat dipergunakan sebagai sarana atau peralatan untuk bermain yang mengandung nilai edukatif dan dapat mengembangkan seluruh aspek perkembangan peserta didik (Mayke Sugianto). Alat permainan edicatif ini dirancang dan digunakan supaya peserta 
didik dapat bermain dan belajar, sehingga ada peningkatan dalam aspek perkembangan peserta didik, karena anak usia dini akan lebih nyaman belajar apabila diikuti dengan gerakan dan permainan. Direktorat PADU, Depdiknas (2003) mendefinisikan alat permainan educatif sebagai sesuatu atau peralatan untuk bermain yang mengandung nilai edukatif (pendidikan) dan dapat megembangkan seluruh kemampuan peserta didik.

Alat permainan edukatif pada intinya berfungsi untuk mengenal lingkungan dan membimbing peserta didik untuk mengenali kekuatan maupun kelemahan dirinya. Peserta didik secara aktif melakukan kegiatan bermain secara optimal menggunakan seluruh panca inderanya secara aktif. Kegiatan atau permainan yang menyenangkan juga akan meningkatkan aktivitas sel otak mereka. Lebih lanjut, keaktifan sel otak akan membantu proses pembelajaran peserta didik.

Kegiatan pembelajaran sains yang sering dibelajarkan oleh pendidik di TK Tribrata antara lain: Percobaan perubahan warna atau bermain warna, percobaan gunung meletus, percobaan tanah longsor, percobaan memasukan benda kedalam air (terapung/melayang/tenggelam), percobaan terjadinya hujan, dan mengungkapkan asal mula terjadinya sesuatu; misalnya gula berasal dari tebu dan lain sebagainya. Kegiatan pembelajaran sains yang dibelajarkan oleh pendidik di TK Tribrata hampir sama dengan kegiatan pembelarajan sains yang ada di lembaga TK/PAUD yang lain. Tidak hanya itu, Alat Permainan Edukatif (APE) yang digunakan juga beragam terutama alat permainan educatif indoor. Alat permainan edukatif indoor yang digunakan, beberapa diantaranya seperti: menara gelang, permainan alat-alat musik, permainan huruf/angka, permainan kendraan, permainan puzzle, kuda-kudaan, dan rambu-rambu lalu lintas. Sedangkan alat permainan edukatif outdoor seperti ayunan besi.

Berdasarkan observasi yang dilakukan oleh peneliti di TK Tribrata yang berlokasi di Desa Tupa Kecamatan Bulango Utara Kabupaten Bone Bolango, ditemukan bahwa setiap proses pembelajaran yang dilakukan pendidik di TK Tribrata lebih sering menggunakan Alat Permaina Edukatif yang sudah ada disekolah atau yang sudah jadi dan atau dibeli seperti, media kompetiftif yaitu huruf-huruf yang sudah jadi, dan media reserpatif yaitu gambar-gambar yang 
sudah jadi. Sedangkan pendidik jarang memanfaatkan alat permainan edukatif yang tersedia dilingkungan sekitar untuk dijadikan media bermain peserta didik. Sementara itu dilingkungan sekolah ada banyak sekali barang yang mendukung untuk dijadikan alat permainan yang bernilai edukatif bagi peserta didik TK/PAUD. Pada kenyataannya proses pembelajaran menggunakan barang yang berasal dari lingkungan sekitar sering diabaikan oleh pendidik, dengan alasan menyita waktu dan media yang digunakan tidak bertahan lama. Akibatnya peserta didik menjadi bosan dengan kegiatan pembelajaran yang menggunakan media belajar yang hanya itu-itu saja. Hal ini tentunya berdampak lanjut pada kurangnya pengalaman belajar langsung yang diperoleh peserta didik, serta rendahnya minat peserta didik dalam mengikuti pembelajaran.

\section{METODE PENELITIAN}

Penelitian ini dilakukan di Desa Tupa Kecamatan Bulango Utara, Kabupaten Bone Bolango, Provinsi Gorontalo. Populasi dalam penelitian ini adalah peserta didik di TK Tribrata Desa Tupa adalah sebanyak 46 peserta didik, dan sampel yang diambil peserta didik sebanyak 30 peserta didik yang dibagi menjadi dua kelas yaitu 15 peserta didik untuk kelas eksperimen dan 15 peserta didik untuk kelas kontrol.

\section{Uji Validitas Instrumen}

Menurut Zainal Ariffin (2012) Validitas adalah suatu derajat ketepatan atau kelayakan instrumen yang digunakan untuk mengukur apa yang akan diukur. Suatu instrument dikatakan valid apabila mampu mengukur yang diinginkan dan mengungkap data variabel yang di teliti secara tepat. Pengujian validitas internal instrument pengaruh alat permainan edukatif berbasis lingkungan terhadap pembelajaran sains ini dilakukan dengan melakukan pengujian validitas empirik. Instrumen dikatakan valid apabila hasilnya sesuai dengan kriteria atau dapat mengukur secara tepat. Untuk mengetahui ke validan instrumen, maka digunakan SPSS 16. 
Butir soal dikatakan valid apabila nilai $r_{\text {hitung }}>r_{\text {tabel }}$ Maka soal dikatakan valid. Jika nilai $r_{\text {hitung }}<r_{\text {tabel }}$ Maka soal dikatakan tidak valid. Interprestasi terhadap nilai koefisien rxy digunakan kriteria sebagai berikut :

Tabel 1. Interprestasi Korelasi

\begin{tabular}{|cc|}
\hline Nilai & Keterangan \\
\hline $0,00-0,20$ & Korelasi sangat rendah \\
$0,20-0,40$ & Korelasi rendah \\
$0,40-0,70$ & Korelasi sedang \\
$0,70-0,90$ & Korelasi tinggi \\
$0,90-1,00$ & Korelasi sangat tinggi \\
\hline
\end{tabular}

Tabel 2. Rekapitulasi Output Validitas Hasil Uji Coba Intrumen Pemanfaatan APE berbasis lingkungan terhadap hasil pembelajaran sains

\begin{tabular}{|cccc|}
\hline $\begin{array}{c}\text { No item } \\
\text { Soal }\end{array}$ & Nilai $\mathbf{r}^{\text {hitung }}$ & $\begin{array}{c}\text { Nilai } \mathbf{r}^{\text {tabel }} \\
\mathbf{N = 1 5} \\
\mathbf{d f}=\mathbf{n - 2}\end{array}$ & Ket \\
\hline 1 & 0,749 & 0,553 & Valid \\
\hline 2 & 0,938 & 0,553 & Valid \\
\hline 3 & 0,938 & 0,553 & Valid \\
\hline 4 & 0,913 & 0,533 & Valid \\
\hline 5 & 0,966 & 0,553 & Valid \\
\hline 6 & 0,891 & 0,553 & Valid \\
\hline 7 & 0,933 & 0,553 & Valid \\
\hline 8 & 0,901 & 0,553 & Valid \\
\hline 9 & 0,901 & 0,553 & Valid \\
\hline 10 & 0,923 & 0,553 & Valid \\
\hline 11 & 0,718 & 0,553 & Valid \\
\hline 12 & 0,832 & 0,553 & \\
\hline
\end{tabular}

\section{Uji Reliabilitas Instrumen}

Instrumen yang telah diuji validitas kemudian diuji reliabilitasnya. Menurut Sugiono (2005) Reliabilitas adalah serangkaian pengukuran atau serangkaian alat ukur yang memiliki konsistensi bila pengukuran yang dilakukan dengan alat ukur itu dilakukan secara berulang.

Reliabilitas menunjukkan pada suatu pengertian bahwa suatu instrument dapat dikatakan mempunyai taraf kepercayaan yang tinggi jika instrument tersebut dapat memberikan hasil yang tetap. Maka pengertian Reliabilitas tes berhubungan dengan masalah ketetapan hasil. Untuk menguji reliabilitas instrument tes digunakan SPSS 16. 
Tabel 3. Interpretasi Korelasi Rehabilitas

\begin{tabular}{|cc|}
\hline Nilai & Keterangan \\
\hline $0,00-0,20$ & Korelasi sangat rendah \\
$0,20-0,40$ & Korelasi rendah \\
$0,40-0,70$ & Korelasi sedang \\
$0,70-0,90$ & Korelasi tinggi \\
$0,90-1,00$ & Korelasi sangat tinggi \\
\hline
\end{tabular}

Berikut ini, hasil uji Reliabilitas dengan menggunakan Cronbach Alpha's. Perhitungan dilakukan setelah mendelet item tidak valid. Data diolah dengan menggunakan program komputer SPSS versi 16.

Tabel 4. Output Reliabilitas Hasil Uji Coba Instrumen Pengaruh APE Berbasis lingkungan terhadap hasil pembelajaran sains

\begin{tabular}{|rr|}
\hline \multicolumn{2}{|c|}{ Reliability Statistics } \\
\hline Cronbach's Alpha & N of Items \\
.974 & 12 \\
\hline
\end{tabular}

Dari hasil pengujian reliabilitas yang dilakukan diperoleh koefisien Cronbach Alpha's $(\alpha) .=0,974$. Berdasarkan pada pedoman kriteria reliabilitas diatas artinya derajat reliabel intrumen berada pada kategori sangat tinggi. Dengan demikian intrumen yang digunakan sudah baik dan dapat dipercaya sebagai alat pengumpul data, sehingga kegiatan penelitian dapat dilanjutkan pada proses selanjutnya.

\section{HASIL DAN PEMBAHASAN}

\section{Hasil}

a) Data Pretest Pada Kelas Eksperimen dan Kelas Kontrol

Berdasarkan analisis data pada Kelas Eksperimen dan Kelas Kontrol diketahui bahwa nilai rata-rata $($ mean=M) di kelas eksperimen sebesar 18,66 sedangkan di kelas kontrol sebesar 16.40. Nilai mean ini mendeskripsikan bahwa nilai rata-rata antara kedua kelas tidak berbeda secara signifikan.

Median atau nilai tengahnya (Me) di kelas eksperimen sebesar 17.00 sedangkan pada kelas kontrol sebesar 15.00, artinya dari nilai median ini yaitu 
bahwa pada umumnya nilai median di kedua kelas hampir sama. Modus (Mo) di kelas eksperimen sebesar 12.00 sedangkan pada kelas kontrol sebesar 12.00, yang berarti nilai modus ini menggambarkan bahwa pada umumnya nilai modus kedua kelas peserta didik sama.

Perhitungan standar deviasi (SD) kelas eksperimen sebesar 7.96 sedangkan di kelas kontrol sebesar 6.31, artinya nilai SD ini mendeskripsikan tingkat keragaman nilai pada kedua kelas tidak jauh berbeda atau bisa disebut perbedaan kedua kelas tidak terlalu signifikan. Kemudian yang terakhir dilihat dari nilai maksimum dan nilai minimum. Pada kelas eksperimen diketahui maksimum sebesar 38 dan nilai minimum 12, sedangkan pada kelas kontrol nilai maksimum 36 dan nilai minimum 12. Artinya dari kedua kelas ini juga terlihat perbedaannya tidak jauh berbeda atau tidak terlalu signifikan.

Dengan demikian dapat disimpulkan bahwa dari nilai mean, median, modus, SD, nilai minimum dan nilai maksimum di antara kelas eksperimen dan kelas kontrol sangat kecil. Hal ini berarti bahwa nilai pretest tersebut menunjukkan keadaan awal kedua kelas tidak berbeda secara signifikan. Karena perbedaan diharapkan muncul setelah diberikannya perlakuan.

b) Data Posttest Pada Kelas Eksperimen Dan Kelas Kontrol

Berdasarkan analisis data pada Kelas Eksperimen daan Kelas Kontrol diketahui nilai rata-rata $($ mean $=\mathrm{M})$ yang didapat di kelas eksperimen sebesar 29.7 sedangkan di kelas kontrol sebesar 22.4. Nilai mean ini berarti bahwa antara kedua kelas tersebut terjadi perbedaan dengan selisih 7.3 poin, sehingga perbedaannya dikatakan cukup signifikan. Selanjutnya perhitungan median (Me) atau nilai tengahnya yang didapat di kelas eksperimen sebesar 27.00 sedangkan di kelas kontrol sebesar 20.00.

Perhitungan modus (Mo) di kelas eksperimen sebesar 24 sedangkan di kelas kontrol sebesar 12. Perhitungan standar deviasi (SD) di kelas eksperimen sebesar 8.67 sedangkan pada kelas kontrol sebesar 1.04. Kemudian nilai maximum dan minimum yang didapat di kelas eksperimen nilai maksimumnya sebesar 45 dan nilai minimum 12, sedangkan di kelas kontrol nilai maksimum 44 dan nilai minimum 12. Terlihat perbedaannya tidak jauh berbeda. Dengan 
demikian dapat disimpulkan dari nilai mean, median, modus, SD, nilai minimum dan nilai maksimum pada kelas eksperimen dan kelas kontrol cukup signifikan perbedaannya.

Dapat disimpulkan bahwa di kelas eksperimen dan kelas kontrol terdapat perbedaan setelah diberikan perlakuan, dalam hal ini setelah penggunaan Alat Permainan Edukatif berbasis lingkungan seperti tanah liat dan botol bekas pada kelas eksperimen cukup baik. Ini merupakan sesuatu yang positif sebab faktor penggunaan Alat Permainan Edukatif berbasis lingkungan cukup berpengaruh untuk pembelajaran sains peserta didik.

a. Uji Normalitas Data

1) Uji Normalitas Pretest Kelas Eksperimen dan Kelas Kontrol

Berdasarkan data hasil pretest di kelas eksperimen dan kelas kontrol, diketahui dengan taraf signifikan sebesar 0,05 setelah data dimasukan ke dalam rumus maka diperoleh nilai $r_{\text {hitung }}$ dengan melihat signifikansi Sig. (2tailed) sebesar 0,344. Dimana berdasarkan dasar pengambilan keputusan $\mathrm{r}_{\text {hitung }}>0.05$ maka data dapat disimpulkan berdistribusi normal.

2) Uji Normalitas Posttest Kelas Eksperimen dan Kelas Kontrol

Berdasarkan data hasil pretest pada kelas eksperimen dan kelas kontrol, diketahui dengan taraf signifikan sebesar 0,05 setelah data dimasukan ke dalam rumus maka diperoleh nilai $r_{\text {hitung }}$ dengan melihat signifikansi Sig. (2-tailed) sebesar 0,639. Dimana berdasarkan dasar pengambilan keputusan $\mathrm{r}_{\text {hitung }}>0.05$ maka data dapat disimpulkan berdistribusi normal.

b. Uji Homogenitas Data

Uji homogenitas dilakukan untuk mengetahui apakah kedua kelas mempunyai varian yang sama atau tidak. Uji homogenitas pada penelitian ini menggunakan Statistik Deskriptif Analyze - Descriptive Statistics - Explore. Hasil penghitungan uji homogenitas data pembelajaran sains peserta didik ditunjukkan pada tabel berikut: 


\section{1) Hasil Uji Homogenitas Pretest Kelas Eksperimen dan Kelas Kontrol}

Berdasarkan data hasil pretest di kelas eksperimen dan kelas kontrol, diketahui bahwa dengan taraf signifikan sebesar 0,05 setelah data dimasukan ke dalam rumus maka diperoleh nilai $\mathrm{r}_{\text {hitung }}$ dengan melihat signifikansi Sig. (2-tailed) sebesar 0,620. Dimana berdasarkan dasar pengambilan keputusan $r_{\text {hitung }}>0.05$ maka data dikatakan memiliki varian yang sama atau homogen. Sedangkan sebaliknya jika $r_{\text {hitung }}<0.05$ maka data dikatakan tidak memiliki varian yang sama atau tidak homogen.

2) Hasil Uji Homogenitas Posttest Kelas Eksperimen dan Kelas Kontrol

Berdasarkan data hasil posttest di kelas eksperimen dan kelas kontrol, diketahui bahwa dengan taraf signifikan sebesar 0,05 setelah data dimasukan ke dalam rumus maka diperoleh nilai $r_{\text {hitung }}$ dengan melihat signifikansi Sig. (2-tailed) sebesar 0,565. Dimana berdasarkan dasar pengambilan keputusan $r_{\text {hitung }}>0.05$ maka data dikatakan memiliki varian yang sama atau homogen. Sedangkan sebaliknya jika $r_{\text {hitung }}<0.05$ maka data dikatakan tidak memiliki varian yang sama atau tidak homogen.

\section{Pembahasan}

Pada kelas eksperimen proses pembelajaran sains dilakukan menggunakan Alat Permainan Edukatif berbasis lingkungan sedangkan di kelas kontrol proses pembelajaran sains menggunakan Alat Permainan Edukatif yang sudah jadi (instan) atau yang sering digunakan oleh pendidikan. Sebelum dimulai atau diberikan perlakuan maka penulis memberikan tes berupa pretest untuk mengetahui keadaan awal dan setelah diberikan perlakuan maka penulis memberikan posttest untuk melihat hasil yang akan dicapai atau diharapkan. Penilaian atau soal yang diberikan kepada peserta didik sudah lebih dahulu di uji validitas dan reliabilitas dengan 12 butir item soal.

Hasil analisis data yang didapatkan dari pretest baik kelas eksperimen maupun kelas kontrol diperoleh bahwa masing-masing kelas mempunyai keadaan awal yang berbeda, hal tersebut dapat dibuktikan dari hasil uji normalitas dan homogenitas. Masing-masing data kelas antara eksperimen maupun kontrol 
berdistribusi normal dengan rata-rata 18.6 dan 16.4 dan kedua kelas mempunyai varians yang sama atau homogen. Hasil analisis data dari posttest menunjukkan hasil dari kedua kelas bahwa data berdistribusi normal dan bervariansi sama atau homogen dengan rata-rata 29.7 dan 22.4.

Berdasarkan penelitian, masih banyak peserta didik yang mendapat nilai BB (Belum Berkembang) dengan skor nilai 50-59 di kelas eksperimen dan kelas kontrol. Seperti pada penilaian Posttest dari kedua kelas, yang mendapat nilai BB (Belum Berkembang) tidak jauh berbeda. Di kelas eksperimen ada sekitar 10 peserta didik yang mendapat nilai BB, sedangkan di kelas kontrol sekitar 12 peserta didik. Hal ini dikarenakan beberapa faktor yang di temukan oleh peneliti di lapangan. Faktor yang menyebabkan masih adanya peserta didik yang mendapat nilai BB (Belum Berkembang), di kelas eksperimen dan kelas kontrol, antara lain: a.) diakibatkan oleh usia anak yang belum cukup untuk memahami pembelajaran sains yang diajarkan oleh pendidik, b) dikarenakan suasana belajar yang kurang mendukung, sehingga menggangu fokus peserta didik dalam memperhatikan pembelajaran sains, c) proses penelitian yang dilakukan oleh peneliti tidak teratur secara berkelompok, tapi secara random atau acak (sesuai jumlah peserta didik yang ada pada saat dilakukannya penelitian).

Solusi yang tepat dalam mengatasi faktor penyebab peserta didik mendapat nilai belum berkembang di atas, yaitu pendidik diharapkan bisa memberikan perhatian lebih terhadap peserta didik tersebut. Karena dalam hal ini, mereka masih memiliki daya tangkap yang kurang, yang menyebabkan mereka mengalami kesulitan dalam menangkap apa yang dijelaskan pendidik pada saat pembelajaran berlangsung.

Kemudian berdasarkan hasil uji hipotesis penelitian menggunakan Uji-t maka dapat disimpulkan bahwa nilai $r_{\text {hitung }}<0.05$ Ha diterima yang artinya bahwa terdapat pengaruh yang signifikan dalam pembelajaran sains peserta didik dengan penggunaan Alat Permainan Edukatif berbasis lingkungan. 


\section{SIMPULAN}

Berdasarkan hasil penelitian disimpulkan bahwa Alat Permainan Edukatif berbasis lingkungan berupa tanah liat dan botol bekas terbukti berpengaruh cukup signifikan terhadap hasil pembelajaran sains di kelompok eksperimen. Pembelajaran sains yang diberi perlakuan (kelas eksperimen) lebih tinggi dibandingkan dengan kelompok peserta didik yang tidak diberi perlakuan (kelas kontrol).

Berdasarkan perhitungan yang dilakukan dengan bantuan program SPSS versi 16 diketahui besarnya nilai t pada output SPSS 16 setelah dilakukan uji analisis (Independent Sampel t-test) diperoleh nilah Sig (2-tailed) sebesar 0.039 dan nilai ini $<$ dari 0,05 , sedangkan dari hasil $t_{\text {hitung }}$ diperoleh nilai sebesar 2,166 dan $>$ dari $t_{\text {tabel }} 2,048$. Karena nilai Sig (2-tailed) $<\propto$ atau $t_{\text {hitung }}$ maka Ha diterima dan Ho ditolak.

\section{DAFTAR PUSTAKA}

Arifin, Zainal. 2012. Penenlitian Pendidikan Metode dan Paradigma Baru. Bandung: Remaja Rosda Karya.

Nugraha, Ali. 2008. Pengembangan Pembelajaran Sains Pada Anak Usia Dini. Bandung.

Putra, Sitiatava Rizema. 2013. Desain Belajar Mengajar Kreatif Berbasis Sains. Yogyakarta: Diva Press.

Sudono, Anggani. 2000. Sumber Belajar dan Alat Permainan (Untuk Pendidikan Anak Usia Dini). Jakarta. PT Grasindo.

Sugiyono. 2005. Memahami Penelitian Kualitatif. Bandung: CV. Alfabeta.

Sugiyono. 2012. Metode Penelitian Kuantitatof, Kualitatif, dan R\&D. Bandung: Alpabeta

Sugiyono. 2014. Metode Penelitian Kuantitatif, Kualitatif, dan $R \& D$. Cetakan ke 20. Bandung: Alpabeta

Suyanto. 2005. Konsep Dasar Anak Usia Dini. Jakarta. Departemen Pendidikan Nasional 